ISSN 1466-1535

\title{
Pay differences between teachers and other occupations: Some empirical evidence from Bangladesh
}

Research Paper 58 November 2005

by Mohammad Niaz Asadullah SKOPE, Department of Economics, University of Oxford

ESRC funded Centre on Skills, Knowledge and Organisational Performance Oxford and Warwick Universities 


\section{Editor's Foreword}

\section{SKOPE Publications}

This series publishes the work of the members and associates of SKOPE. A formal editorial process ensures that standards of quality and objectivity are maintained.

Orders for publications should be addressed to the SKOPE Secretary, SKOPE, Warwick Business School, University of Warwick, Coventry CV4 7AL 


\begin{abstract}
This paper addresses a popular debate on teacher pay in a developing country context, namely whether teachers are under-paid or over-paid. Using national level household survey data from Bangladesh, we find that teachers are significantly under-paid in comparison to non-teachers who possess similar human capital and other observed characteristics. A decomposition exercise of the teacher non-teacher wage gap reveals that the teacher non-teacher salary difference is driven mostly by differential returns to observed characteristics and not by differences in the endowment of those characteristics. Our results suggest that there is some equity justification for allowing an "across-the-board" increase in teacher pay particularly for female, rural and aided school teachers in Bangladesh.
\end{abstract}

JEL Classification: J31, I20, J40, H52.

Key Words: Teacher salaries, wage-gap decomposition.

\footnotetext{
* An earlier version of the paper was presented at VI METU International Conference in Economics, Turkey. I am thankful to Simon Appleton, Geeta Kingdon and John Knight for comments and suggestions. However, any remaining errors and omissions are mine.Fax+44-1865-281488.

Corresponding-mail:Mohammad Asadullah@economics.ox.ac.uk
} 


\section{Introduction}

Teacher pay is among the frequently debated school inputs hypothesised to have an important bearing on student learning ${ }^{1}$. Pay policy, it is argued, performs various direct as well as indirect roles which have important implications for teachers as inputs in the educational production process. Higher teacher pay is thought to affect student achievement by raising incentives for the existing teachers to better teach their students for efficiency wage type reasons. For example, higher relative teacher pay keeps the opportunity costs of teaching low, thereby allowing schools to retain better quality teachers who otherwise have superior outside opportunities. In addition, superior pay may improve the overall quality of teachers in school: higher pay attracts a larger pool of potential teachers from which schools can select. As such, the likelihood of adverse selection into the teaching occupation is reduced, i.e. the quality of new recruits also improves.

Due to the importance of teacher incentives, dissatisfaction is commonly expressed about the fact that teachers are not adequately paid. Not surprisingly, this issue has received a great deal of attention in the economics literature on teacher pay. Recent studies that have looked at the issue of relative pay of teachers are Grootaert and Komenan (1990), Psacharopoulos et al. (1996), Piras and Savedoff (1998), Vegas et al. (1999), Liang (1999) and Lopez-Acevedo (2002) ${ }^{2}$. Despite popular beliefs, for some countries it has been found that teachers are not paid less than comparable workers in the labour market. For example, Grootaert and Komenan (1990) in their study of teacher non-teacher pay gaps for Cote d'Ivoire did not find significant evidence of the problem. Psacharopoulos et al. (1996) looked at the issue for Latin America and found no clear pattern of over- or under-payment across the region. However, their results are difficult to generalise as they do not control for various covariates of earnings ${ }^{3}$. Using large scale census data, Vegas et al. (1999) also failed to find convincing evidence that teachers are always worse off (pay-wise) than non-teachers in Argentina. Piras and Savedoff (1998) find that hourly earnings of teachers are comparable to or even better than similar workers in other occupations in Bolivia. They argue that such an earnings premium should help recruit, motivate, and retain more qualified individuals in the teaching profession.

In contrast with Africa and Latin America, however, the question of low relative teacher pay is under-researched for South Asia. There exists significant concern over low teacher pay in South Asian countries. For example, Haq and Haq (1998) claim that 
observed salary for primary school teachers in Pakistan is less than that received by a cook, gardener or even a chauffeur. The situation is perhaps not very different for Bangladesh. As can be seen from Table 1, average teacher pay as a multiple of per capita income in Bangladesh is less than that in India, Pakistan and Bhutan. However, we are not aware of any study which objectively examines the validity of the claim low relative pay of teachers - using South Asian data. The existing studies on the issue of teacher pay either explore the determinants of pay (e.g. Khan, 2002) and/or effect of pay on student achievement (e.g. Kingdon and Teal, 2005).

Table 1: Teacher pay in South Asia

\section{Sri Lanka}

Nepal

Bangladesh

India

Pakistan

Bhutan

\section{Average Primary Teacher Salary as Multiple of GDP per capita}

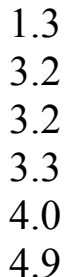

4.9

Source: Bray (2002)

Popular demands for teacher salary reform in South Asia are seldom based on objective comparison of teacher pay relative to their productivity or relative to the pay of similar individuals in the labour market. In the absence of any systematic empirical evidence, we do not know whether the claim that teachers are poorly paid is true. It may be that teachers are less productive/qualified than other workers in comparable jobs, in which case the wage differentials are mostly reflecting their low human capital endowment. Or perhaps, they enjoy better work flexibility or shorter work hours for which they accept lower pay. This compensating differentials hypothesis aside, existing theories of wage determination provide no a priori economic basis to expect systematic underpayment of teachers in relation to others in the labour market. Thus, a natural question that arises in this context is: how does teacher salary compare with the salary of other comparable wage earning groups, for example people with similar educational attainment?

The objective of this paper is to address the issue of relative teacher pay. For Bangladeshi data, our result suggests a large negative wage premium for teachers, particularly for female, urban and aided school teachers. Whether this result is affected by non-random selection into the teaching occupation could not be determined due to a 
lack of valid exclusion restrictions. Nonetheless, the estimates control for types of school attended and hours worked by sample individuals, and are robust to selection into wage work. We attempt to provide further insights by decomposing the teacher non-teacher wage differential into the component arising due to differences in average characteristics of teachers (T) and non-teachers (NT) and the component due to differences in occupation-specific returns to a given characteristic. The rest of the paper is organised as follows. First, in section 2, we provide an overview of the labour market for teachers in Bangladesh. In section 3, we discuss the empirical strategy. Section 4 discusses the data. Section 5 reports the main results and section 6 concludes.

\section{Background on the teacher labour market in Bangladesh}

The private sector is the largest employer of teachers in Bangladesh. Nevertheless, the labour market for educational personnel is not characterised by a situation of monopsony: a significant number of teachers are also employed in the public and nonprofit sectors. As discussed later, the majority of private schools in Bangladesh receive substantial financial support from the government. Employment contracts and salaries in these schools mimic that of a semi-government regime. In addition to public and private schools, a fraction of the primary schools are run by non-government organisations (NGOs) which educate dropouts from mainstream primary schools. At the secondary level, however, no such NGO schools operate. The majority of secondary schools are privately owned. In this section, we discuss the nature of demand for teachers in Bangladesh and their supply with reference to the public-private divide in the labour market.

\subsection{Demand for teachers}

The demand for teachers is derived from the growth in student population, number of (new and existing) schools and policies to allocate students per teacher. The primary and secondary education sectors in the country have undergone substantial expansion in the past two decades. However, growth in the total number of teachers has been outstripped by that in the number of students in the primary as well secondary sectors ${ }^{4}$.

The key factor that determines composition of the teaching force on the demand side is the process underlying recruitment of new teachers. Like most other occupations in the economy, the teacher selection process is a competitive one although it varies somewhat across the private, government and semi-government sectors. Teachers of 
aided schools (semi-government sector) are recruited by concerned school management committees (SMCs) on the basis of relevant government rules. On the other hand, teachers of government secondary schools are recruited centrally by the directorate of secondary (and higher) education through a competitive examination. Similar practice applies to government primary schools. Different NGOs pursue different policies regarding recruitment of teachers. Some NGOs prepare a short-list of prospective teachers on the basis of a rigorous test, and recruit teachers from this short-list, while others recruit teachers from the locally available interested persons, rather informally ${ }^{5}$. Recruitment of teachers in government primary and secondary schools through competitive examinations conducted by respective Directorates ensures reasonable standards in the quality of teachers. Quality is pre-defined in terms of observable characteristics such as educational attainment, subject in which a graduate degree was acquired, previous training and experience.

However, there is one aspect of the recruitment process even here that somewhat undermines the extent of this competitiveness. The policy of a gender-based quota at the primary level requires 60 percent of the teachers in a school to be female (for whom the educational qualification has been relaxed). Entry qualification for a newly recruited primary school teacher is the secondary school certificate (SSC) for females and the higher secondary certificate (HSC) for males. A SSC implies 10 years of schooling and a HSC entails 12 years of schooling. No sex difference exists in salaries and opportunities for promotion, however.

\subsection{Entry into teaching: the supply side}

The nature of the supply of teachers remains fuzzy in Bangladesh. Like many other developing countries, graduates of any discipline are eligible to apply for teaching positions in a school. The minimum required qualification for entry into primary teaching has been fixed by the government as graduation in HSC examination with Certificate-in-Education, or a Bachelor Degree for males. Females do not require any certification apart from SSC (PMED, 1999). On the other hand, the minimum requirement for teaching in secondary schools is a bachelor degree without the necessity of a teacher training certificate. This is in contrast with developed countries where individuals pre-qualify for entry into the teaching market conditional on certifications from the state authority and/or holding a graduate degree in education. In such a case, the initial stock of teachers is easily determined in terms of the total number of 
graduates who have received certifications or professional training. The absence of a (initial) vetting process makes the teaching market relatively attractive for new labour force entrants in developing countries compared to those in the developed economies. However, the key factors in the decision to enter the teaching profession and remain therein seem to be the level and structure of pay (and service conditions) relative to other occupations.

In Bangladesh educational personnel in the public sector are paid as per government specified salary scale. Pay is pre-determined on the double basis of educational qualifications and experience and is unrelated to work performance. In such a rigid compensation structure, internal promotion is based on seniority. Internal salary hierarchies within the teaching profession correspond to the level at which teachers are deployed: secondary school teachers earn more than their primary colleagues do. Whether such uniform or single salary schedule applies to the handful of private schools that operate without government aid (mostly in the urban area) is, however, not known.

Approximately 50 percent of the primary schools, 98 percent of the secondary schools and 99 percent of the madrasas in Bangladesh operate in the private sector. For the majority of such schools, pay of educational personnel closely follows public sector salary structure because almost all the recognised schools/madrasas in Bangladesh receive regular aid from the government towards payment of teacher salaries. In 1999, the government contribution accounted for 80 percent of basic salaries, house rent and medical allowances to teachers appointed against sanctioned posts of all aided secondary schools. The rest is financed by the school from its own earnings ${ }^{6}$. Thus aided school teachers typically have somewhat lower salaries than government school teachers. Moreover, only the government schools offer a pension in post-retirement years. These differential incentives have caused much tension in the country's education sector. Aided school teachers have been demanding the equalisation of salary levels in the aided and public education sectors. Additionally, teachers of all sectors in general perceive their pay to be relatively low. However, the exact nature of the comparator group remains illusive. The perception of underpayment could be due to a subjective (and unrealistic) choice of comparator occupations that do not serve as genuine alternatives to teaching jobs. The majority of the teachers in Bangladesh are graduates in non-education related disciplines and view employment in rather a wide range of occupations as credible alternatives to teaching. This is at contrast to developed countries, where the majority of teachers are education graduates and for whom 
alternative job opportunities are well-defined. Opportunity wages of teachers in other jobs are often overstated. It is therefore not clear whether monetary incentives to teach are indeed inadequate in the Bangladeshi education sector.

If the existing claims for under-payment of educational personnel are true, this should be mirrored by teacher shortages across the country; fewer people would select the teaching regime despite high demand. Indeed there is some anecdotal evidence that schools are facing difficulties in filling vacant teaching posts, particularly in rural $\operatorname{areas}^{7}$. Such vacancies relate either to newly created posts or arise following individual exits from teaching due to better professional opportunities outside the education field. In the absence of reliable data on teacher attrition, it is difficult to distinguish between these two possibilities. Irrespective of the underlying cause, such vacancies cannot be taken as conclusive evidence of a genuine teacher shortage. Much of the vacancies are in the aided sector and they often reflect bureaucratic delays on the part of the Ministry of Education to sanction/approve new teachers and fiscal difficulties of the government.

If anything, there is a general shortage of employment opportunities in the economy; a significant part of the educated working-age population remains unemployed. The notion of teacher shortage (as a signal for underpayment of teachers) is further diluted by the absence of a teacher certification system in the country; prior training or pedagogical qualification is not mandatory for a teaching job. For this reason, one cannot determine shortfall in terms of the initial pool of "potential teachers" from which schools can recruit, as is often the case in developed countries. A general shortage of educational personnel is nonetheless perceived to prevail in a qualitative sense. For example, in subject areas such as English and Science, schools allegedly experience a serious shortage of teachers. At the primary level, years of schooling completed by teachers is also worrisome: 43 percent of them have at most lower secondary qualification, equivalent to only 8 years of schooling (Siniscalco, 2002).

\section{Empirical strategy}

It is intended to compare teacher salaries with salaries of other comparable individuals in the labour market i.e. to examine the premium earned or deficit suffered by teachers. The conventional approach to modelling teachers ( $\mathrm{T}$ ) non-teachers (NT) wage differential includes an occupation (teaching) dummy intercept in a statistical earnings function controlling for individual characteristics which are supposed to capture the productivity differentials. We follow the same approach and estimate a pooled wage 
regression using data on salaried workers who have at least 10 years of education. The dependent variable is adjusted for differential work hours across occupations: we report estimates of differentials in hourly (instead of monthly) earnings only ${ }^{8}$. Wages are nonetheless observed only for participants in the labour market and this sub-sample may not be a random one because individuals may self-select (or be hierarchically selected) into wage employment on the basis of some unobservables (e.g. ability) which also affect wages. If so, the OLS estimate of wage premium will be biased ${ }^{9}$. To overcome this problem, we additionally report wage regressions for the pooled sample of $\mathrm{T}$ and NT (with a dummy for teachers) correcting for self-selection into wage work, following Heckman (1979).

In order to identify the lambda term in the wage regression, we use three variables in the first stage probit model that are excluded from the wage regression. First two variables are measures of unearned income: (a) money received from sales of assets and lands and (b) income received from other sources such as land leasing, rents, insurance policy, windfall gains such as lottery awards, money received through intrahousehold transfer, remittances and so on. The third exclusion restriction is household land size. Land ownership is likely to increase productivity of self-employment type activities and hence reduce the probability of participation in waged work, but it is unlikely to affect wages. All these variables are excluded from the earnings function as they are assumed to affect only the decision to participate in waged work, not earnings.

The above strategy is restrictive in the sense that the pay difference is limited only to an intercept term by having an occupational dummy variable specification; variations in the slope coefficients are not exploited. When the structure of wages is permitted to differ across two groups (e.g. teachers and non-teachers), the gross or raw inter-group difference in wages can be decomposed using the familiar Oaxaca-Blinder (OB) method. The OB decomposition technique involves separation of the sample into teachers and non-teachers and estimating separate wage equations. Mean differences in the explanatory variables in the teaching and non-teaching sectors are then weighted by a "non-discriminatory" wage structure - which prevails in the absence of discrimination - to estimate waged differentials.

Following this approach, one can examine how much of the average wage-gap between teachers and non-teachers can be explained by differences in the productive characteristics of teachers and non-teachers and how much is not explained by T-NT characteristics differences (the residual component). If the latter, unexplained, 
component is substantial, then one may argue that there is a premium (or deficit) in teacher salaries as compared with non-teacher salaries, which is not due to their superior (or inferior) human capital characteristics relative to non-teachers.

The literature on the $\mathrm{OB}$ approach lacks a consensus in what could serve as the correct non-discriminatory wage-structure. Often, the dominant group's (i.e. nonteacher) wage structure is applied both to the teaching and non-teaching sectors as the non-discriminatory wage structure. However, additional weighting schemes are also available: (i) teacher wage structure (ii) the weighted average of the teacher and nonteacher wage structure ${ }^{10}$ and (iii) vector of coefficients from a pooled regression with teacher and non-teachers combined. In this study, we use the non-discriminatory wage structure derived from the pooled sample of teachers and non-teachers. This method is superior as it is derived from the economic theory of discrimination. However, robustness of our results to alternate weighting schemes is discussed later in the empirical section.

Lastly, some important caveats on wage gap decomposition. The decomposition approach to earning differentials is sensitive to omitted variable bias and model misspecification (as is also the case with the dummy variable approach to modelling earning differentials). In addition, by splitting the sample to fit separate earning functions for teachers and non-teachers, we face an occupational selection problem. Indeed there are two selection issues here: selection into waged work and, conditional on waged work, selection into teaching and non-teaching occupations. If selection into teaching and non-teaching is endogenous, selectivity corrected earnings functions should be used in an amended decomposition framework as proposed by Neuman and Oaxaca (2004). We do not elaborate the Neuman and Oaxaca approach here as we do not make recourse to selectivity corrected decomposition analysis in this paper. As discussed later, we do not find significant evidence of sample selection in our data.

\section{Data description}

We use data from the Household Income and Expenditure Survey (HIES) 2000 survey conducted by the Bangladesh Bureau of Statistics (BSS). This is a nationally representative household survey which covers 7440 households and is similar in design to the World Bank's Living Standard Measurement Surveys (LSMS) for other developing countries. To look at the issue of relative teacher pay, we construct a sample of wage earners where everyone has at least 10 years of education and is aged 19 years 
and above. The HIES 2000 reports a sample of 12118 working people (aged 19 years or older) in various economic activities such as wage employment or self-employed in agricultural or non-agricultural activities. Among these individuals, 1907 working persons have (i) educational attainment equivalent to 10 years or more and (ii) (reported) total monthly hours of work of at least 50. Focusing on this restricted sample allows comparability of earnings of teachers with others in the labour market. Of these 1907 individuals, 981 are in non-wage self-employment activities. The remaining 926 are wage workers of whom 266 individuals (29\%) are in teaching. Table 2 describes the characteristics of the working sample. The reported mean hourly wages for teachers and non-teachers are 17.33 and 22.14 taka respectively. Among other notable contrasts, teachers are more likely to work in the semi-government sector than non-teachers. The mean educational attainment of teachers is also higher. Females are more likely to be in teaching. Lastly, teachers are more concentrated in rural areas in comparison to nonteachers.

Further comparison of raw wage data of teachers with those of other comparable individuals in various occupations also suggests that teachers systematically receive less pay relative to other occupations. Apart from sales and security personnel, the mean pay of teachers is lower than that of all other occupations. The results are summarised in Table 3.

An alternative comparison is presented in Table 4 aggregating workers by sector of work, gender and work location. Mean teacher salary is significantly lower than that for non-teachers in all but public and private sub-samples. However, any comparison of raw earnings by occupation category, gender, sector of work and so on is only indicative. It is difficult to say anything on the basis of such a comparison because of (a) small size of occupation-specific samples, (b) differences in job characteristics across sectors and (c) individual differences in observed and unobserved characteristics. 
Table 2: Characteristics of working sample

\begin{tabular}{|c|c|c|c|c|}
\hline \multirow[t]{2}{*}{ Variable Name } & \multirow[t]{2}{*}{ Description } & Pooled & Teachers & teachers \\
\hline & & mean sd & mean sd & mean sd \\
\hline Total hourly & & 20.7614 .6 & 17.3312 .2 & 22.1415 .2 \\
\hline $\begin{array}{l}\text { Total hourly } \\
\text { earnings }\end{array}$ & in $\log s$ & 2.810 .70 & 2.620 .72 & 2.890 .68 \\
\hline Experience & Age-6-schooling & 20.6710 .9 & 20.611 .7 & 20.710 .6 \\
\hline Experience_sq & (Experience Squared)/100 & 5.465 .25 & 5.615 .67 & 5.405 .07 \\
\hline Female & $(1=\text { if female })^{*}$ & 0.130 .34 & 0.270 .44 & $0.08 \quad 0.27$ \\
\hline Non Muslim & $(1=\text { Non Muslim })^{*}$ & 0.120 .33 & 0.120 .33 & 0.130 .33 \\
\hline Rural & $(1=\text { Rural workplace })^{*}$ & 0.300 .46 & 0.580 .50 & 0.200 .40 \\
\hline Teacher & $(1=\text { teacher })^{*}$ & 0.290 .45 & $-\quad-$ & $-\quad-$ \\
\hline \multicolumn{5}{|l|}{ Schooling } \\
\hline SSC & $(1=\text { if SSC passed })^{*}$ & 0.310 .46 & 0.200 .40 & 0.360 .48 \\
\hline HSC & $(1=\text { if HSC passed })^{*}$ & 0.270 .44 & 0.280 .45 & 0.260 .44 \\
\hline BA & $(1=\text { if } B A)^{*}$ & 0.250 .43 & 0.270 .44 & 0.240 .43 \\
\hline MA & $(1=$ if $M A) *$ & 0.140 .35 & 0.240 .43 & 0.100 .30 \\
\hline
\end{tabular}

Type of school attended

\begin{tabular}{|c|c|c|c|c|}
\hline Aided school & $(1=\text { attended aided school })^{*}$ & 0.540 .50 & 0.520 .50 & 0.550 .50 \\
\hline Public school & $\begin{array}{l}(1=\text { attended government school })^{*} \\
(1=\text { attended private unaided }\end{array}$ & 0.330 .47 & 0.340 .47 & 0.320 .47 \\
\hline Private school & school) $*$ & 0.100 .30 & 0.080 .27 & 0.110 .31 \\
\hline $\begin{array}{l}\text { Religious school } \\
\text { Sector of work }\end{array}$ & $(1=\text { attended religious school })^{*}$ & 0.030 .17 & 0.060 .24 & 0.020 .13 \\
\hline Govt. & $\begin{array}{l}(1=\text { works in government sector })^{*} \\
(1=\text { works in semi-government }\end{array}$ & 0.360 .48 & 0.280 .45 & 0.390 .49 \\
\hline Semi govt. & $\begin{array}{l}\text { sector })^{*} \\
(1=\text { works in non-government }\end{array}$ & 0.250 .43 & $0.46 \quad 0.5$ & 0.170 .37 \\
\hline Non Govt. & sector $)^{*}$ & 0.270 .45 & 0.100 .30 & 0.340 .47 \\
\hline LG_NGO & $(1=\text { works in NGO sector })^{*}$ & 0.050 .22 & 0.050 .21 & 0.050 .22 \\
\hline Other & $(1=\text { works in other sectors })^{*}$ & 0.060 .25 & 0.110 .32 & 0.050 .21 \\
\hline $\mathbf{N}$ & & 926 & 266 & 660 \\
\hline
\end{tabular}


Table 3: Teacher pay relative to other occupations

\begin{tabular}{lccc}
\hline & Mean salary (in logs) & Relative teacher pay & $\mathbf{N}$ \\
\cline { 2 - 4 } Teacher & 17.33 & --- & 266 \\
Engineers/Technicians & 30.95 & 0.56 & 31 \\
Medical Professions & 22.19 & 0.78 & 50 \\
Accountants & 24.91 & 0.70 & 39 \\
Other Professionals & 30.11 & 0.58 & 31 \\
Clerk & 20.65 & 0.84 & 110 \\
Transport Workers & 21.63 & 0.80 & 32 \\
Sales Personnel & 14.53 & 1.19 & 38 \\
Security Personnel & 16.08 & 1.08 & 36 \\
Agriculturists & 20.92 & 0.83 & 13 \\
Others & 22.77 & 0.76 & 280 \\
N & --- & --- & 926 \\
\hline
\end{tabular}

Notes: All Individuals have at least 10 years of education (i.e. SSC passed) and aged over 18 years. Relative teacher pay $=$ Teacher pay/ (pay in a given non-teaching occupation).

Table 4: Mean pay of teachers and non-teachers by worker characteristics

\begin{tabular}{lccc}
\hline & Teacher & Non-teacher & t-test \\
\cline { 2 - 4 } Full Sample & 17.32 & 22.13 & -4.50 \\
Male Sample & 18.49 & 22.43 & -3.12 \\
Female Sample & 14.12 & 18.60 & -2.49 \\
Urban Sample & 20.63 & 23.38 & -1.69 \\
Rural Sample & 14.88 & 17.00 & -1.75 \\
Public Sample & 24.06 & 24.99 & -0.51 \\
Private Sample & 14.26 & 23.06 & -1.50 \\
Semi-govt Sample & 16.47 & 19.46 & -4.13 \\
\hline
\end{tabular}

Note: $t$-test corresponds to difference of means.

\section{Main findings}

\subsection{Hourly earnings functions with occupation (teacher) dummy}

Table 5 reports estimates of the wage premium earned by teachers i.e. coefficients on teacher dummy variable in regressions using the pooled sample of teachers and nonteachers. For the sake of brevity, however, Table 5 suppressed other covariates of wage earnings such as experience, education, school type attended, gender, sector of work and regional (i.e. district) fixed-effects. The coefficient on the teacher dummy in Table 5 is significantly negative for the full sample. A negative wage premium is reported for various sub-samples and is significant for all samples, although only weakly so for the female sample. The weak significance of the coefficient on teacher dummy for the female sample is perhaps due to small sample size but the point estimate on teacher dummy is large. 
Table 5: OLS and Heckman estimates of coefficient on teacher dummy in pooled wage regression

\begin{tabular}{|c|c|c|c|c|c|c|}
\hline & & Full & Male & Female & Urban & Rural \\
\hline \multirow[t]{2}{*}{ estimate) } & Teacher dummy & $\begin{array}{r}-0.176 \\
(3.50)^{* *}\end{array}$ & $\begin{array}{c}-0.122 \\
(2.10)^{*}\end{array}$ & $\begin{array}{r}-0.260 \\
(1.94)\end{array}$ & $\begin{array}{c}-0.159 \\
(2.27)^{*}\end{array}$ & $\begin{array}{l}-0.172 \\
(2.02)^{*}\end{array}$ \\
\hline & Adjusted $\mathbf{R}^{2}$ & 0.40 & 0.37 & 0.49 & 0.40 & 0.33 \\
\hline \multirow[t]{3}{*}{$\begin{array}{l}\text { (Heckman } \\
\text { Estimate) }\end{array}$} & Teacher dummy & $\begin{array}{r}-0.172 \\
(3.60) * *\end{array}$ & $\begin{array}{r}-0.12 \\
(2.25)^{*}\end{array}$ & - & $\begin{array}{c}-0.162 \\
(2.56)^{*}\end{array}$ & $\begin{array}{c}-0.158 \\
(2.12)^{*}\end{array}$ \\
\hline & $\begin{array}{l}\text { Mills ratio } \\
\text { (lambda) }\end{array}$ & $\begin{array}{r}-0.31 \\
(1.88)+ \\
0.17\end{array}$ & $\begin{array}{r}-0.329 \\
(1.70)+ \\
0.15\end{array}$ & - & $\begin{array}{r}-0.181 \\
-0.83 \\
0.14\end{array}$ & $\begin{array}{r}-0.121 \\
-0.89 \\
0.23\end{array}$ \\
\hline & $\mathbf{N}$ & 926 & 804 & 122 & 644 & 282 \\
\hline
\end{tabular}

Notes: Dependent variable is hourly earnings. Each regression also controls for experience, experience squared, gender, years of schooling, type of school attended by the individual, sector of work and district fixed-effects. Robust (Huber-white correction for heteroskedasticity) t-statistics in parenthesis. + significant at $10 \% ; *$ significant at $5 \%$; ** significant at $1 \%$. Heckman model for female sample could not be estimated due to small sample size.

In addition to the OLS estimates, the selectivity-corrected estimate is also reported in Table 5. Mean values of the identifying variables and their definitions are provided in Appendix Table 1. As discussed earlier, we use household land holdings, income from sales of various assets and rents earned from various other sources (e.g. remittances, leasing household assets and so on) as exclusion restrictions in the selection model. Higher unearned income and rents in general significantly decrease waged work participation. Similarly, landholdings negatively affect participation in waged work, perhaps because landholdings raise returns to self-employment type activities. The identifying variables in most cases have negative coefficients and are jointly statistically significant. The sample selection correction term 'lambda' is insignificant for all the sub-samples at 5\% level. Even in cases where the lambda terms are weakly significant, their inclusion had no impact on the estimated coefficient on the teacher dummy. For example, the coefficients on teacher dummy in the selectivity corrected pooled earnings functions for the full and male samples are -.172 and -.120 respectively (significant at $10 \%$ level), remarkably similar to the OLS coefficients. Consequently, OLS is preferred throughout the paper.

Splitting the main sample further by sector of employment (i.e. government vs. non-government) provides additional insights (Table 6). Within the government sector, teachers are not paid any less than non-teachers (column 1). The absence of a T-NT wage gap in this sample is not puzzling because salaries of individuals across 
occupations within the public sector are determined by the same employer, and it is likely that in the government sector, inter-occupation comparability is important. In any case, the wage structure across occupations is generally more compressed in the public sector. Turning to the "non-government" sector sample (column 2 of Table 6), we find a significant T-NT wage gap. That is, within the sector combining private, semigovernment, NGO and local-government sectors, the estimated wage gap is large and significant, indicating that school teachers are paid less in comparison to others within the non-government sector. However, the non-government sample contains a good deal of heterogeneity. Given the differences in school management types in Bangladesh, the segregation of teachers by school type is important. There are, in general, three types of schools: (i) public, (ii) private, and (iii) aided. Depending on school type, teacher salary varies substantially in Bangladesh even within the non-government sector. Hence, the wage gaps experienced by teachers are also likely to differ across sub-sectors within the non-government sector.

Table 6: OLS estimates of coefficient on teacher dummy in pooled wage regression, by sector of work

\begin{tabular}{|c|c|c|c|c|c|c|}
\hline & Govt. & Non-govt. & Private (1) & Private (2) & Semi-govt. & NGO \\
\hline $\begin{array}{l}\text { Teacher } \\
\text { dummy }\end{array}$ & $\begin{array}{l}-0.064 \\
(0.79)\end{array}$ & $\begin{array}{r}-0.225 \\
(3.14)^{* *}\end{array}$ & $\begin{array}{r}-0.084 \\
(0.66) \\
\end{array}$ & $\begin{array}{r}-0.031 \\
(0.21) \\
\end{array}$ & $\begin{array}{r}-0.362 \\
(3.71)^{* *}\end{array}$ & $\begin{array}{r}-0.574 \\
(1.05) \\
\end{array}$ \\
\hline $\mathbf{N}$ & 334 & 532 & 299 & 253 & 233 & 46 \\
\hline Adjusted $\mathbf{R}^{2}$ & 0.34 & 0.41 & 0.41 & 0.37 & 0.45 & 0.86 \\
\hline
\end{tabular}

We allow for this possible heterogeneity by further splitting the "nongovernment" sample (Column 2) into various sub-sectors of employment ${ }^{11}$. The HIES 2000 classifies "non-government" individuals in the labour market into three subsectors: (1) non-government (i.e. private), (2) semi-government, (3) NGO-Local government ${ }^{12}$. Aided school teachers are contained in the "semi-government" sector here. Regressions specific to these sectors are reported in Table 6. Column 3 reports estimates excluding "semi-government sector" individuals from column (2) sample. Interestingly, the T-NT wage gap becomes insignificant. The finding remains unchanged when we report results for purely private sector (further excluding NGO and 
local government individuals from column (3) sample) in column 4. This finding appears consistent with the neo-classical theory which predicts that increased competition reduces scope for discrimination across race, gender, occupation types and so on. Since private schools compete with other private enterprises in the labour market for recruitment of teachers, salary differences are small and insignificant after controlling for observed individual characteristics.

Column 5 reports estimates for the semi-government sub-sample only. The TNT wage gap for the semi-government employees is significant and large indicating that (aided school) teachers are paid less in comparison to non-teachers within the semigovernment sector. An even larger T-NT wage is reported for the local government and NGO sector although it is insignificant perhaps due to a very small sample size.

It is noteworthy that comparing teachers with non-teachers within the semigovernment sector is problematic. Within this sector, most of the teachers are employed in the aided schools. Although these schools are partly financed by the government, they are entirely privately owned. In contrast, semi-government organisations are autonomous organisations although under greater control of the government. Hence, we also carry out separate analysis lumping the teachers in the semi-government sector with those in the purely private sector. Non-teachers reported in the semi-government sector are re-classified as government sector employees. However, this reorganisation of our sample observations does not change our conclusion at all (results are suppressed). There is still no evidence of under-payment of teachers in the public and private sector samples. This leads to the interesting conclusion that the biggest segmentation of the labour market is along government-private lines. Within the government sector, teachers are paid no less than the non-teachers. Within the private sector (which includes the aided school teachers), teachers are also paid no less than non-teachers. However, when government and private sectors are merged, as in the full sample (Table $6)$, there is indeed a significant positive wage-premium for non-teachers. 
Table 7: Age-cohort specific estimates of earnings regressions with teacher dummy

\begin{tabular}{lrrrr}
\hline & Age 19-28 & Age 29-38 & Age 39-48 & Age 49-58 \\
\cline { 2 - 5 } Teacher & & & & \\
dummy & -0.021 & -0.222 & -0.243 & -0.280 \\
& $(0.19)$ & $(2.09)^{*}$ & $(2.07)^{*}$ & $(1.41)$ \\
\cline { 2 - 5 } $\mathbf{N}$ & 220 & 276 & 259 & 141 \\
Adjusted R & 0.24 & 0.30 & 0.30 & 0.24 \\
\hline
\end{tabular}

Notes: Dependent variable is hourly earnings. Each regression also controls for experience, experience squared, gender, years of schooling, type of school attended by the individual, sector of work and district fixed-effects. Robust (Huber-white correction for heteroskedasticity) t-statistics in parenthesis. * significant at $5 \% ; * *$ significant at $1 \%$.

Lastly, Table 7 provides estimates of T-NT wage gaps for sub-populations representing different age-cohorts ${ }^{13}$. As such, the Table shows how wage-differences experienced by younger cohorts of teachers compare with those of older cohorts. The gap is apparently increasing across age-cohorts though the point-estimates are not (statistically) significantly different. This implies that as a teacher moves across the career ladder, he/she receives less and less wage in comparison to individuals with similar background and age-cohort in the labour market ${ }^{14}$. This suggests that the experience-earnings profile is flatter for teachers compared with non-teachers, as is also evident in Figure $1^{15}$. While for non-teachers the usual inverted U-shaped experienceearnings profile is observed, for teachers it is more like a flat straight line. Similar profiles are produced for various sub-samples in Figures 2-5. In all the figures, teacher earnings are lower than earnings of non-teachers across different years of experience holding other characteristics constant at their mean values. In early years, the earnings gap is small or non-existent for full sample, males and urban wage workers. However, this may also be the result of a cohort effect: it may be that in recent years, among new recruits, there is little T-NT wage differentials.

But teachers' earning profiles diverge rapidly from those of non-teachers with a rise in experience. For the full and male samples, T-NT profiles converge in the later years. The exceptions are female and rural samples where there appear to be large earnings differentials even in the very early years in the job market. For the female sample, this gap persists at all levels of experience. In the rural labour market, the earnings profile of teachers is also lower than that of non-teachers at all levels of experience although it rises greatly in the later years, faster than that of non-teachers.

These findings have serious policy implications: given the existing salary scheme, school managers may find it more difficult to retain teachers in the urban 
sector. For rural schools (which employ the majority of school teachers in Bangladesh), the challenge is much greater as teachers at all levels of experience face lower earnings than non-teachers. Hence, both attracting as well as retaining individuals in teaching in the rural areas are relevant concerns.

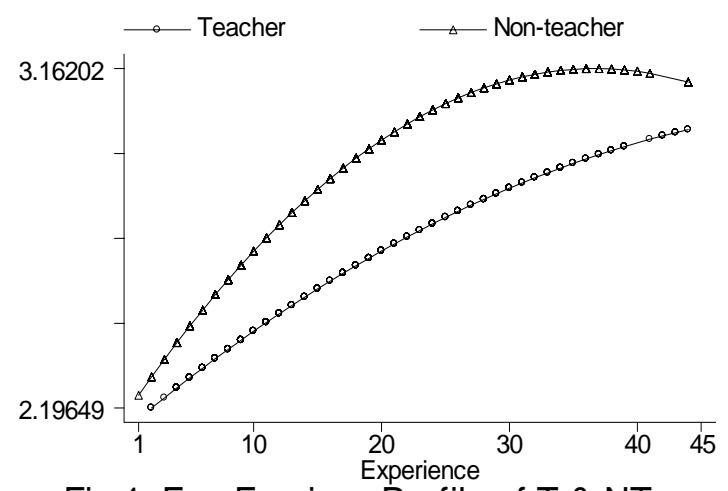

Fig 1: Exp-Earnings Profile of T \& NT

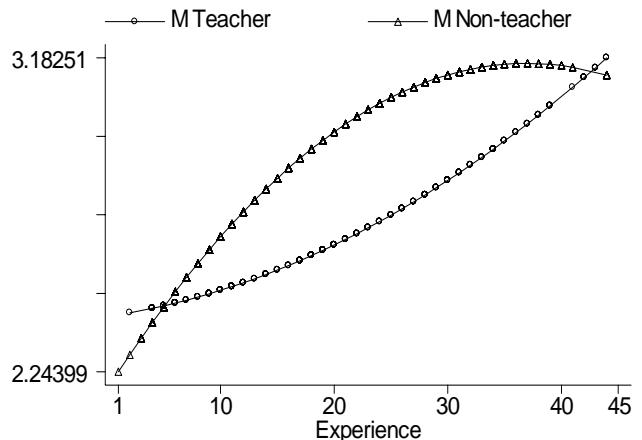

Fig 2: Exp-Earnings Profile of Male T \& NT

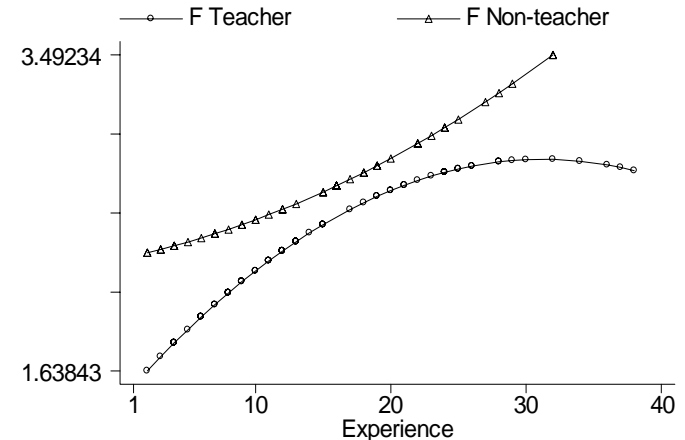

Fig 3: Exp-Earnings Profile of Female T \& NT

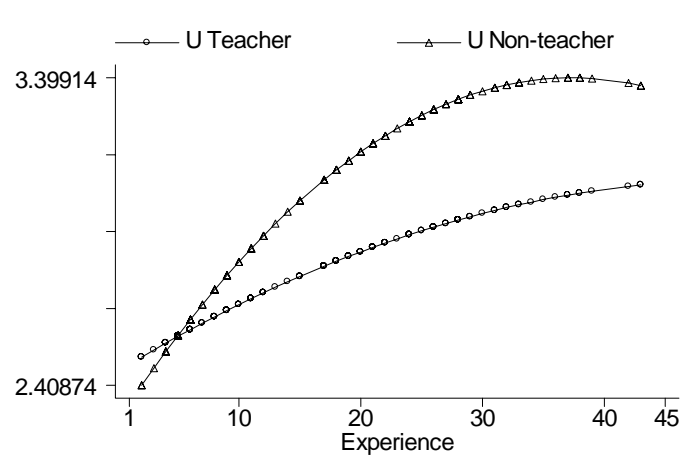

Fig 4: Exp-Earnings Profile of Urban T \& NT

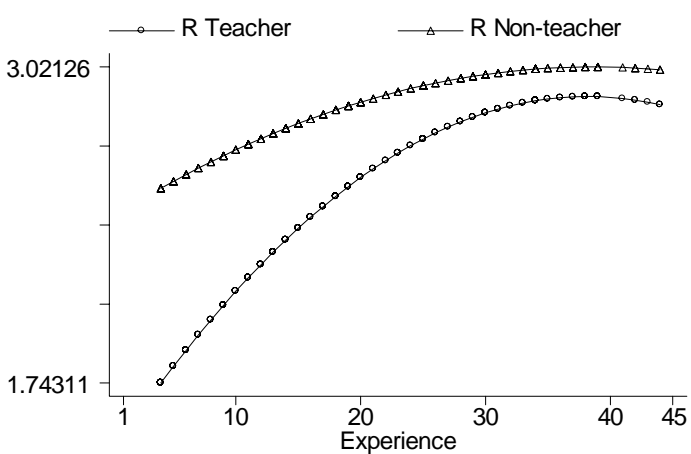

Fig 5: Exp-Earnings Profile of Rural T \& NT 


\subsection{Decomposing T-NT wage gaps}

Table 8 below presents results from the decomposition analysis. The regression coefficients underlying the decomposition exercise are derived from the OLS earnings function reported in Appendix Tables 3 and 4. Since mean NT pay is significantly higher than mean T pay (see Tables 2 and 3), we decompose NT-T mean pay gaps. The wage structure obtained from regressions reported in Appendix Table 4 is used to weigh differences in observed characteristics of the individuals. It should be noted that an attempt was also made to correct for selection into teaching and non-teaching occupations. However, we do not have data on variables that could a priori predict selection into teaching or non-teaching jobs but do not determine earnings. We nevertheless estimated Heckman's two-step model of wage earnings for teachers and non-teachers using as exclusion restrictions household landholding and non-earned income, the same set of the variables which were used earlier for correcting selection into wage work. However, the lambda terms were not significant at conventional levels. Hence, we have discarded these Heckman estimates in the Oaxaca decomposition analysis ${ }^{16}$.

Table 8: Decomposing NT-T wage gap using pooled salary structure as weights

\begin{tabular}{lcc|c}
\hline Sample & $\begin{array}{c}\text { Explained due to } \\
\text { characteristics } \\
\text { difference }\end{array}$ & $\begin{array}{c}\text { Unexplained due to } \\
\text { coefficient difference }\end{array}$ & Total wage gap \\
\cline { 2 - 4 } Full & $.103(38)$ & $.167(62)$ & .271 \\
Male & $.077(38)$ & $.126(62)$ & .203 \\
Female & $-.162(-210)$ & $.240(342)$ & .077 \\
Urban & $-.004(-2)$ & $.167(102)$ & .163 \\
Rural & $-.045(-36)$ & $.170(136)$ & .125 \\
Government & $.005(16)$ & $.026(84)$ & .031 \\
Private & $.126(48)$ & $.132(52)$ & .259 \\
Semi-govt & $.160(43)$ & $.218(57)$ & .379 \\
\hline
\end{tabular}

Note: Figures in parenthesis are percentages of total wage gap.

For the full sample, $62 \%$ of the estimated NT-T wage difference is attributed to differential returns to productivity endowments and hence attributable to "discrimination". Additional sub-sample specific estimates of wage gaps are also reported in Table 8 . For example, only $38 \%$ of the NT-T wage gap for the male sample is due to differences in characteristics. For the urban sample, the residual component accounts for $102 \%$ of the wage gap. Similarly, for the rural sample, $136 \%$ of the 
observed wage gap is attributed to the residual component. For the semi-government sector, the result is consistent with earlier findings: $57 \%$ of the NT-T wage gap is attributable to the residual component and hence indicates substantial under-payment of teachers net of their characteristics differences with non-teachers. This is true even for the private sector where $52 \%$ of the NT-T wage gap remains unexplained. Hence, this reverses our earlier finding (from pooled regression with occupation dummy) that private sector teachers are not underpaid.

Estimates for the female sample provide some additional insights. Dominance of the residual component of the wage gap over the productivity differential component clearly shows that teachers are indeed discriminated against in the female labour market. However, a sizable estimate of productivity differential (-.162 in logs) suggests that this is the case despite female teachers having a superior productivity endowment in comparison to female non-teachers in the labour market such as higher levels of education. Similar is the situation for rural labour market: despite a residual pay gap of .17 , teachers in reality experience a somewhat smaller pay gap due to a superior productivity endowment (-.045).

We also repeated the decomposition analysis using three alternate proxies for non-discriminatory wage schemes: (a) an average wage structure (constructed by assigning equal weight to T and NT wage structure), (b) non-teachers' wage structure and (c) teachers' wage structure. Comparison of Table 8 to estimates emanating from application of these three alternative sets of weights indicates that our estimates are somewhat sensitive to the choice of non-discriminatory wage structures or weights. However, use of different weights mostly affected the relative size of the residual component in our different decomposition analyses; it did not change the quantitative conclusion. To be precise, the index number issue does not affect the balance of our conclusion in this study.

In sum, results from both approaches (i.e. earnings functions with occupation dummy and decomposition of NT-T wage gaps using separate earnings functions) are in general consistent with each other. Higher share of residual component in the T-NT wage gap yield evidence in support of the common perception that teachers in Bangladesh are "under-paid" relative to other individuals of similar characteristics in the labour market. 


\section{Conclusion}

Our analysis of the wage data on teachers and non-teachers using recent national household survey shows that teachers are significantly under-paid in comparison to people of similar human capital and other characteristics in Bangladesh. This finding is robust to smaller work hours in teaching, and sample selectivity due to non-random participation in waged work. When analysed by sector of employment, it is the aided school teachers (i.e. those in the semi-government sector) who appear most disadvantaged: within the public and private sectors teachers do not experience low pay in comparison to non-teachers once differences in the observed characteristics are controlled. Further, the estimated wage gap is significantly larger for older cohorts of teachers implying that school managers may face significant difficulty in retaining individuals in teaching at the current salary level especially in areas of low unemployment among the educated. Attracting educated individuals to teaching may be a challenge in the case of females and rural populations given our evidence of a large earnings differential even at the entry level for female and rural samples. Low relative pay of teachers may also partly explain the incidence of teacher attrition in some parts of the country. Hence, an increase in the relative pay of teachers can aid schools in teacher retention and recruitment in rural areas.

However, despite various robustness tests, we are somewhat restricted in our ability to decisively conclude that teachers are being significantly underpaid or discriminated against since we could not control for differences between teachers and non-teachers in unobserved characteristics. Also, occupation specific selection issues remained unresolved due to lack of valid exclusion restrictions. Keeping these caveats in mind, our findings suggest that there is possibly an equity justification for allowing an increase in teacher pay in Bangladesh particularly in the semi-government sector.

Nonetheless, it is not known whether an across-the-board increase in teacher pay is an efficient policy option, given the current pay structure in Bangladesh. That is, we do not know whether higher teacher pay boosts student achievement in Bangladesh. A mere increase in salary level for all teachers without a specific link to teacher performance may not translate into superior quality of new teachers (Ballou and Podgursky, 1997a) or higher effort by the existing ones. Furthermore, the policy may not be equally feasible at all levels. For example, most of the primary school teachers are employed in the rural area where across-the-board salary increases can create a new type of adverse selection: higher salaries may attract candidates with strong political or 
social connections which may have other risks such as encouraging lack of teacher accountability and widening the social distance between teacher and the (rural poor) students ${ }^{17}$. In addition, a further increase in teacher salary is difficult to achieve in a developing country like Bangladesh where the salary bill already consumes around $90 \%$ of the total recurrent expenditure by schools. Hence, policy makers and school managers may have to rethink other non-pecuniary benefits (such as improving working conditions) offered to teachers and the current salary structure before considering an across-the-board salary increase. 
Appendix Table 1: Summary statistics of sample used in Heckman estimate of pooled wage regression

\begin{tabular}{|c|c|c|c|}
\hline Variable & Definition & Mean & Std. Dev. \\
\hline Wage participant & $\overline{\text { Dummy (1= if wage worker) }}$ & 0.486 & 0.500 \\
\hline Experience & Age-6-schooling & 21.590 & 11.364 \\
\hline Experience_sq & (Experience Squared)/100 & 5.952 & 5.742 \\
\hline Female* & $(1=$ Female $)$ & 0.074 & 0.263 \\
\hline Non Muslim* & $(1=$ Non Muslim $)$ & 0.127 & 0.333 \\
\hline Rural location* & (1= Rural workplace) & 0.460 & 0.499 \\
\hline SSC* & $(1=$ if SSC passed $)$ & 0.397 & 0.489 \\
\hline HSC* & $(1=$ if HSC passed) & 0.273 & 0.446 \\
\hline BA* & $(1=$ if $B A)$ & 0.205 & 0.404 \\
\hline MA* & $(1=$ if $\mathrm{MA})$ & 0.103 & 0.304 \\
\hline Public school* & (1= attended government school) & 0.294 & 0.456 \\
\hline Aided school* & $(1=$ attended aided school $)$ & 0.578 & 0.494 \\
\hline Private school* & (1=attended private school & 0.098 & 0.297 \\
\hline Religious school* & $(1=$ attended religious school $)$ & 0.028 & 0.166 \\
\hline \multicolumn{4}{|c|}{ Variables used in Keckman selection model (for exclusion restrictions) } \\
\hline Non-labour income1 & $\begin{array}{l}\text { Income earned from sales of land or } \\
\text { other assets }\end{array}$ & 342.74 & 2088.96 \\
\hline Non-labour income2 & $\begin{array}{l}\text { Income from lottery, remittances and } \\
\text { renting out land }\end{array}$ & 3362.13 & 18809.41 \\
\hline Land size & Total household landholding (in acres) & 1.58 & 5.72 \\
\hline $\mathbf{N}$ & & 1907 & \\
\hline
\end{tabular}

Notes: Sample consists of all wage employees, aged 19 years or over, who have at least 10 years of schooling. * indicates that the variable is a dummy. SSC stands for secondary school certificate examination, a national level test taken after completion of grade 10. Similarly, HSC is a national level examination taken after completion of grade 12 . 
Appendix Table 2: OLS estimates of earnings regressions, teachers

\begin{tabular}{|c|c|c|c|c|c|c|c|c|}
\hline & Full & Male & Female & Urban & Rural & Govt & Private & Semi-govt \\
\hline \multirow{2}{*}{ Experience } & 0.02 & 0.01 & 0.05 & 0.00 & 0.05 & 0.05 & -0.05 & 0.04 \\
\hline & $(1.48)$ & $(0.55)$ & $(2.69)^{* *}$ & $(0.20)$ & $(2.51)^{*}$ & $(2.40)^{*}$ & $(0.90)$ & $(1.76)+$ \\
\hline \multirow[t]{2}{*}{ Experience_sq } & -0.01 & 0.01 & -0.07 & 0.04 & -0.06 & -0.07 & 0.17 & -0.03 \\
\hline & $(0.40)$ & $(0.13)$ & $(1.50)$ & $(0.93)$ & $(1.51)$ & $(1.90)+$ & $(1.89)+$ & $(0.70)$ \\
\hline \multirow[t]{2}{*}{ Female } & -0.21 & & & -0.28 & 0.01 & 0.00 & 0.23 & -0.25 \\
\hline & $(2.46)^{*}$ & & & $(2.08)^{*}$ & $(0.08)$ & $(0.02)$ & $(0.46)$ & $(1.56)$ \\
\hline \multirow[t]{2}{*}{ Non Muslim } & 0.00 & 0.12 & -0.26 & 0.13 & -0.07 & 0.01 & -1.06 & 0.13 \\
\hline & $(0.01)$ & $(0.90)$ & $(1.63)$ & $(0.85)$ & $(0.48)$ & $(0.07)$ & $(1.95)+$ & $(1.05)$ \\
\hline \multirow[t]{2}{*}{ Rural } & -0.35 & -0.45 & 0.03 & & & -0.13 & -0.63 & -0.36 \\
\hline & $(4.55)^{* *}$ & $(4.74)^{* *}$ & $(0.24)$ & & & $(0.88)$ & $(1.15)$ & $(3.45)^{* *}$ \\
\hline \multicolumn{9}{|l|}{ Schooling } \\
\hline \multirow[t]{2}{*}{ HSC } & 0.03 & -0.02 & 0.20 & 0.08 & -0.05 & 0.26 & 0.22 & -0.14 \\
\hline & $(0.32)$ & $(0.18)$ & $(1.48)$ & $(0.49)$ & $(0.45)$ & $(2.05)^{*}$ & $(0.70)$ & $(0.93)$ \\
\hline \multirow[t]{2}{*}{ BA } & 0.20 & 0.26 & 0.08 & 0.19 & 0.25 & 0.29 & 0.54 & 0.27 \\
\hline & $(1.89)+$ & $(2.10)^{*}$ & $(0.32)$ & $(0.93)$ & $(1.86)+$ & $(1.93)+$ & $(1.22)$ & $(1.59)$ \\
\hline \multirow[t]{2}{*}{ MA } & 0.38 & 0.32 & 0.71 & 0.59 & 0.25 & 0.53 & 1.03 & 0.60 \\
\hline & $(3.26)^{* *}$ & $(2.31)^{*}$ & $(3.57)^{* *}$ & $(3.56)^{* *}$ & $(1.46)$ & $(2.67) * *$ & (1.67) & $(3.99)^{* *}$ \\
\hline \multicolumn{9}{|l|}{$\begin{array}{l}\text { Type of school } \\
\text { attended }\end{array}$} \\
\hline \multirow[t]{2}{*}{ Public school } & 0.14 & 0.10 & 0.29 & 0.02 & 0.25 & 0.05 & 0.17 & 0.15 \\
\hline & $(1.79)+$ & $(1.06)$ & $(2.28)^{*}$ & $(0.14)$ & $(2.23)^{*}$ & $(0.41)$ & $(0.55)$ & (1.39) \\
\hline \multirow[t]{2}{*}{ Private school } & -0.12 & -0.12 & -0.04 & -0.49 & 0.14 & -0.08 & -0.75 & 0.23 \\
\hline & $(0.86)$ & $(0.63)$ & $(0.26)$ & $(1.85)^{+}$ & $(1.16)$ & $(0.55)$ & $(1.23)$ & (1.43) \\
\hline \multirow[t]{2}{*}{ Religious school } & 0.03 & 0.04 & 0.00 & -0.01 & 0.17 & & 0.58 & -0.03 \\
\hline & $(0.18)$ & $(0.21)$ & (.) & $(0.05)$ & $(0.67)$ & & $(0.99)$ & $(0.11)$ \\
\hline \multicolumn{9}{|l|}{$\begin{array}{l}\text { Sector of } \\
\text { employment }\end{array}$} \\
\hline \multirow[t]{2}{*}{ Semi govt. } & -0.44 & -0.35 & -0.63 & -0.32 & -0.47 & & & \\
\hline & $(5.61)^{* *}$ & $(3.80) * *$ & $(3.11)^{* *}$ & $(2.34)^{*}$ & $(5.53)^{* *}$ & & & \\
\hline \multirow[t]{2}{*}{ Private } & $(0.46)$ & -0.43 & -0.45 & -0.30 & -0.66 & & & \\
\hline & $(2.99)^{* *}$ & $(2.08)^{*}$ & $(2.35)^{*}$ & $(1.38)$ & $(2.93)^{* *}$ & & & \\
\hline \multirow[t]{2}{*}{ LG_NGO } & -0.95 & -0.84 & -0.90 & -1.00 & -0.91 & & & \\
\hline & $(4.94)^{* *}$ & $(3.98)^{* *}$ & $(3.33)^{* *}$ & $(2.83)^{* *}$ & $(4.61)^{* *}$ & & & \\
\hline \multirow[t]{2}{*}{ Others } & -0.80 & -0.68 & -0.76 & -0.68 & -0.86 & & & \\
\hline & $(5.19)^{* *}$ & $(3.66) * *$ & $(3.65)^{* *}$ & $(3.73)^{* *}$ & $(3.01)^{* *}$ & & & \\
\hline \multirow[t]{2}{*}{ Constant } & 2.72 & 2.82 & 1.98 & 2.88 & 1.99 & 2.05 & 2.49 & 1.91 \\
\hline & $(12.98)^{* *}$ & $(10.65)^{* *}$ & $(7.06)^{* *}$ & $(8.13)^{* *}$ & $(7.08)^{* *}$ & $(4.17)^{* *}$ & $(6.26)^{* *}$ & $(6.54)^{* *}$ \\
\hline $\mathbf{N}$ & 266 & 195 & 71 & 113 & 153 & 75 & 27 & 122 \\
\hline Adjusted $\mathbf{R}^{2}$ & 0.37 & 0.31 & 0.50 & 0.42 & 0.34 & 0.20 & 0.21 & 0.36 \\
\hline
\end{tabular}


Appendix Table 3: OLS estimates of earnings regressions, non-teachers

\begin{tabular}{|c|c|c|c|c|c|c|c|c|}
\hline & Full & Male & Female & Urban & Rural & Govt & Private & $\begin{array}{l}\text { Semi-govt } \\
\end{array}$ \\
\hline \multirow[t]{2}{*}{ Experience } & 0.05 & 0.05 & 0.01 & 0.06 & 0.03 & 0.06 & 0.05 & 0.04 \\
\hline & $(6.83)^{* *}$ & $(6.22)^{* *}$ & $(0.16)$ & $(6.32)^{* *}$ & $(1.92)^{+}$ & $(5.60)^{* *}$ & $(3.29)^{* *}$ & $(2.52)^{*}$ \\
\hline \multirow[t]{2}{*}{ Experience_sq } & -0.07 & -0.06 & 0.08 & -0.08 & -0.04 & -0.08 & -0.06 & -0.04 \\
\hline & $(4.87)^{* *}$ & $(4.46)^{* *}$ & $(0.76)$ & $(4.42)^{* *}$ & $(1.60)$ & $(4.21)^{* *}$ & $(2.21)^{*}$ & (1.33) \\
\hline \multirow[t]{2}{*}{ Female } & 0.00 & & & -0.04 & 0.12 & 0.06 & -0.17 & -0.37 \\
\hline & $(0.03)$ & & & $(0.50)$ & $(0.72)$ & $(0.68)$ & $(1.26)$ & $(0.92)$ \\
\hline \multirow[t]{2}{*}{ Non Muslim } & -0.03 & -0.06 & 0.33 & -0.11 & 0.19 & 0.17 & -0.19 & -0.03 \\
\hline & $(0.54)$ & $(0.94)$ & $(1.56)$ & $(1.51)$ & (1.64) & $(2.17)^{*}$ & $(1.62)$ & $(0.21)$ \\
\hline \multirow[t]{2}{*}{ Rural } & -0.22 & -0.24 & 0.04 & & & -0.22 & -0.23 & -0.11 \\
\hline & $(3.86)^{* *}$ & $(3.97)^{* *}$ & $(0.22)$ & & & $(2.62)^{* *}$ & $(1.96)+$ & $(0.92)$ \\
\hline \multicolumn{9}{|l|}{ Schooling } \\
\hline \multirow[t]{2}{*}{ HSC } & 0.19 & 0.19 & 0.29 & 0.17 & 0.22 & 0.16 & 0.31 & 0.03 \\
\hline & $(3.52)^{* *}$ & $(3.30)^{* *}$ & (1.64) & $(2.91)^{* *}$ & $(1.80)+$ & $(2.20)^{*}$ & $(2.94)^{* *}$ & $(0.24)$ \\
\hline \multirow[t]{2}{*}{ BA } & 0.44 & 0.44 & 0.63 & 0.45 & 0.47 & 0.30 & 0.65 & 0.50 \\
\hline & $(7.69)^{* *}$ & $(7.23)^{* *}$ & $(2.89)^{* *}$ & $(6.95)^{* *}$ & $(3.25)^{* *}$ & $(4.45)^{* *}$ & $(5.47)^{* *}$ & $(3.36)^{* *}$ \\
\hline \multirow[t]{2}{*}{ MA } & 0.74 & 0.73 & 1.33 & 0.76 & 0.71 & 0.63 & 0.92 & 0.91 \\
\hline & $(9.84)^{* *}$ & $(9.27)^{* *}$ & $(8.05)^{* *}$ & $(9.15)^{* *}$ & $(3.26)^{* *}$ & $(6.34)^{* *}$ & $(5.28)^{* *}$ & $(5.70)^{* *}$ \\
\hline \multicolumn{9}{|l|}{$\begin{array}{l}\text { Type of school } \\
\text { attended }\end{array}$} \\
\hline \multirow[t]{2}{*}{ Public school } & 0.07 & 0.07 & 0.21 & 0.09 & -0.01 & 0.11 & 0.01 & -0.03 \\
\hline & $(1.44)$ & (1.19) & (1.10) & $(1.52)$ & $(0.07)$ & $(1.81)^{+}$ & $(0.05)$ & $(0.29)$ \\
\hline \multirow[t]{2}{*}{ Private school } & -0.09 & -0.09 & 0.12 & -0.05 & -0.17 & -0.16 & -0.08 & -0.22 \\
\hline & $(1.33)$ & (1.29) & $(0.42)$ & $(0.72)$ & $(0.83)$ & $(1.60)$ & $(0.74)$ & (1.53) \\
\hline \multirow[t]{2}{*}{ Religious school } & -0.51 & -0.51 & & -0.08 & -0.93 & -0.23 & -0.40 & -1.02 \\
\hline & $(2.72)^{* *}$ & $(2.76)^{* *}$ & & $(0.60)$ & $(2.64)^{* *}$ & $(2.24)^{*}$ & (1.49) & $(1.84)+$ \\
\hline \multicolumn{9}{|l|}{$\begin{array}{l}\text { Sector of } \\
\text { employment }\end{array}$} \\
\hline \multirow[t]{2}{*}{ Semi govt. } & -0.06 & -0.04 & -0.33 & -0.06 & 0.02 & & & \\
\hline & $(1.13)$ & $(0.76)$ & $(0.72)$ & $(0.99)$ & $(0.14)$ & & & \\
\hline \multirow[t]{2}{*}{ Private } & -0.17 & -0.15 & -0.33 & -0.12 & -0.20 & & & \\
\hline & $(2.84)^{* *}$ & $(2.45)^{*}$ & $(1.58)$ & $(1.90)+$ & $(1.29)$ & & & \\
\hline \multirow[t]{2}{*}{ LG_NGO } & -0.19 & -0.18 & -0.20 & -0.08 & -0.50 & & & \\
\hline & $(1.81)+$ & $(1.44)$ & $(1.11)$ & $(0.72)$ & $(2.53)^{*}$ & & & \\
\hline \multirow[t]{2}{*}{ Others } & -0.32 & -0.30 & & -0.28 & -0.33 & & & \\
\hline & $(2.22)^{*}$ & $(2.11)^{*}$ & & $(1.81)^{+}$ & $(0.89)$ & & & \\
\hline \multirow[t]{2}{*}{ Constant } & 2.13 & 2.14 & 2.08 & 2.00 & 2.22 & 2.05 & 1.93 & 2.15 \\
\hline & $(20.98)^{* *}$ & $(19.90)^{* *}$ & $(6.68)^{* *}$ & $(16.92)^{* *}$ & $(11.15)^{* *}$ & $(15.52)^{* *}$ & $(12.65)^{* *}$ & $(10.56)^{* *}$ \\
\hline $\mathbf{N}$ & 660 & 609 & 51 & 531 & 129 & 259 & 226 & 111 \\
\hline Adjusted $\mathrm{R}^{2}$ & 0.33 & 0.32 & 0.40 & 0.33 & 0.23 & 0.31 & 0.26 & 0.34 \\
\hline
\end{tabular}

Notes: Robust t-statistics in parenthesis. + significant at 10\%; * significant at 5\%; ** significant at $1 \%$. The omitted category for employment sector dummies is 'government'; omitted education dummy is 'SSC' and omitted school type dummy is 'aided school'. 
Appendix Table 4: OLS estimates of earnings regressions, pooled sample of teachers and nonteachers

\begin{tabular}{|c|c|c|c|c|c|c|c|c|}
\hline & Full & Male & Female & Urban & Rural & Govt & Private & Semi-govt \\
\hline \multirow[t]{2}{*}{ Experience } & 0.041 & 0.039 & 0.042 & 0.047 & 0.033 & 0.055 & 0.036 & 0.033 \\
\hline & $(6.57)^{* *}$ & $(5.59)^{* *}$ & $(2.39)^{*}$ & $(5.86) * *$ & $(3.11)^{* *}$ & $(6.13)^{* *}$ & $(2.57)^{*}$ & $(2.50)^{*}$ \\
\hline \multirow[t]{2}{*}{ Experience_sq } & -0.051 & -0.046 & -0.039 & -0.058 & -0.042 & -0.075 & -0.032 & -0.028 \\
\hline & $(4.11)^{* *}$ & $(3.46)^{* *}$ & $(0.96)$ & $(3.78)^{* *}$ & $(1.96)+$ & $(4.48) * *$ & $(1.10)$ & $(1.04)$ \\
\hline \multirow[t]{2}{*}{ Female } & -0.180 & & & -0.261 & -0.119 & 0.041 & -0.253 & -0.405 \\
\hline & $(3.18)^{* *}$ & & & $(3.72)^{* *}$ & $(1.29)$ & $(0.62)$ & $(2.18)^{*}$ & $(2.89) * *$ \\
\hline \multirow[t]{2}{*}{ Non Muslim } & -0.032 & -0.028 & -0.046 & -0.093 & 0.081 & 0.131 & -0.220 & 0.071 \\
\hline & $(0.59)$ & $(0.47)$ & $(0.31)$ & $(1.39)$ & $(0.80)$ & $(1.89)+$ & $(1.81)+$ & $(0.75)$ \\
\hline \multirow[t]{2}{*}{ Rural location } & -0.310 & -0.360 & -0.127 & & & -0.188 & -0.334 & -0.443 \\
\hline & $(7.21)^{* *}$ & $(7.74)^{* *}$ & $(1.13)$ & & & $(3.27)^{* *}$ & $(2.86)^{* *}$ & $(6.15)^{* *}$ \\
\hline \multicolumn{9}{|l|}{ Schooling } \\
\hline \multirow[t]{2}{*}{ HSC } & 0.156 & 0.142 & 0.233 & 0.178 & 0.095 & 0.175 & 0.280 & -0.075 \\
\hline & $(3.25)^{* *}$ & $(2.73) * *$ & $(2.02)^{*}$ & $(3.17)^{* *}$ & (1.06) & $(2.83)^{* *}$ & $(2.78) * *$ & $(0.78)$ \\
\hline \multirow[t]{2}{*}{ BA } & 0.379 & 0.395 & 0.355 & 0.418 & 0.286 & 0.288 & 0.587 & 0.308 \\
\hline & $(7.41)^{* *}$ & $(7.28) * *$ & $(2.34)^{*}$ & $(6.78)^{* *}$ & $(2.94) * *$ & $(4.61)^{* *}$ & $(5.12)^{* *}$ & $(2.93) * *$ \\
\hline \multirow[t]{2}{*}{ MA } & 0.595 & 0.578 & 0.851 & 0.722 & 0.333 & 0.576 & 0.756 & 0.609 \\
\hline & $(9.42)^{* *}$ & $(8.40)^{* *}$ & $(4.98)^{* *}$ & $(10.60)^{* *}$ & $(2.50)^{*}$ & $(6.97)^{* *}$ & $(4.40)^{* *}$ & $(5.67)^{* *}$ \\
\hline \multicolumn{9}{|l|}{$\begin{array}{l}\text { Type of school } \\
\text { attended }\end{array}$} \\
\hline \multirow[t]{2}{*}{ Public school } & 0.091 & 0.083 & 0.108 & 0.069 & 0.124 & 0.102 & 0.055 & 0.057 \\
\hline & $(2.09)^{*}$ & $(1.73)+$ & $(1.01)$ & (1.39) & $(1.38)$ & $(1.92)+$ & $(0.49)$ & $(0.71)$ \\
\hline \multirow[t]{2}{*}{ Private school } & -0.087 & -0.074 & -0.195 & -0.098 & -0.034 & -0.137 & -0.137 & 0.002 \\
\hline & $(1.46)$ & $(1.17)$ & $(1.34)$ & $(1.41)$ & $(0.27)$ & $(1.62)$ & $(1.29)$ & $(0.02)$ \\
\hline \multirow[t]{2}{*}{ Religious school } & -0.275 & -0.275 & 0.000 & -0.013 & -0.250 & -0.226 & -0.291 & -0.285 \\
\hline & $(2.08)^{*}$ & $(2.08)^{*}$ & (.) & $(0.11)$ & $(1.23)$ & $(2.44)^{*}$ & $(1.51)$ & $(1.08)$ \\
\hline \multicolumn{9}{|l|}{$\begin{array}{l}\text { Sector of } \\
\text { employment }\end{array}$} \\
\hline \multirow[t]{2}{*}{ Semi govt. } & -0.253 & -0.180 & -0.664 & -0.149 & -0.402 & & & \\
\hline & $(5.64)^{* *}$ & $(3.93)^{* *}$ & $(4.06)^{* *}$ & $(2.68)^{* *}$ & $(5.40)^{* *}$ & & & \\
\hline \multirow[t]{2}{*}{ Private } & -0.227 & -0.194 & -0.401 & -0.150 & -0.414 & & & \\
\hline & $(4.16)^{* *}$ & $(3.35)^{* *}$ & $(2.30)^{*}$ & $(2.37)^{*}$ & $(3.37)^{* *}$ & & & \\
\hline \multirow[t]{2}{*}{ NGO } & -0.318 & -0.181 & -0.596 & -0.203 & -0.576 & & & \\
\hline & $(3.30)^{* *}$ & $(1.56)$ & $(3.47)^{* *}$ & $(1.72)+$ & $(3.54)^{* *}$ & & & \\
\hline \multirow[t]{4}{*}{ Others } & -0.503 & -0.419 & -0.993 & -0.420 & -0.685 & & & \\
\hline & $(4.72)^{* *}$ & $(3.67)^{* *}$ & $(4.59)^{* *}$ & $(3.66)^{* *}$ & $(3.09)^{* *}$ & & & \\
\hline & 2.293 & 2.297 & 2.137 & 2.156 & 2.259 & 2.063 & 2.048 & 2.248 \\
\hline & $(25.61)^{* *}$ & $(23.49)^{* *}$ & $(8.83)^{* *}$ & $(19.58)^{* * *}$ & $(14.83)^{* *}$ & $(16.68)^{* *}$ & $(14.46)^{* *}$ & $(14.42)^{* *}$ \\
\hline & 926 & 804 & 122 & 644 & 282 & 334 & 253 & 233 \\
\hline Adjusted $\mathbf{R}^{2}$ & 0.33 & 0.31 & 0.44 & 0.33 & 0.23 & 0.30 & 0.24 & 0.36 \\
\hline
\end{tabular}

Notes: Robust t-statistics in parenthesis. All the columns above report OLS estimates unless mentioned otherwise. + significant at $10 \%$; significant at $5 \%$; * significant at $1 \%$. The omitted category for employment sector dummies is 'government'; omitted education dummy is 'SSC' and omitted school type dummy is 'aided school'. 


\section{References}

Ballou, Dale (1996) 'Do public schools hire best applicants?', Quarterly Journal of Economics, 30(2), pp. 97-133.

Ballou, Dale and Podgursky, Michael (1997) 'Recruiting smarter teachers', Journal of Human Resources, 30(2), pp. 326-338.

(1997a) Teacher Pay and Teacher Quality (W. E. Upjohn Institute for Employment Research, Michigan).

Blinder, Alan (1973) 'Wage discrimination: Reduced form and structural estimates,' Journal of Human Resources, 8, pp. 436-455.

Bray, Mark (2002) Costs and Financing of Education: Trends and Policy Implications (Asian Development Bank, Manila).

Dolton, Peter and Chung, Tsung-Ping (2004) 'The rate of return to teaching: How does it compare to other graduate jobs?', National Institute Economic Review, 190(1), pp. 89103.

Dréze, Jean and Gazdar, H. (1997) 'Uttar Pradesh: The burden of inertia', in Dréze and Sen (eds.), Indian Development (Clarendon Press, Oxford).

Figlio, David (1997) 'Teacher salaries and teacher quality', Economics Letters, 55(2), pp. 267-271.

Goldhaber, D. and Brewer, D. (1997) 'Why don't schools and teachers seem to matter? Assessing the impact of unobservables on educational productivity', Journal of Human Resources, 32(3), pp. 505-523.

Grootaert, Christiaan, and Komenan, Andre (1990) 'Pay differences between teachers and other occupations: some empirical evidence from Côte d'Ivoire', Economics of Education Review, 9(3), pp. 209-217.

Harbison, Ralph and Hanushek, Erik (1992) Educational Performance of the Poor (Oxford University Press, New York).

Haq, Mahbub-ul and Haq, Khadija (1998) Human Development in South Asia (Oxford University Press, Karachi).

Heckman, James (1979) 'Sample selection bias as a specification error', Econometrica, 47(1), pp. 153-161.

Hussain, Zahid (2000) 'Bangladesh: Education Finance', Bangladesh Education Sector Review, 2 (The World Bank, Dhaka).

Hovey, D. C., Knight, John and Sabot, R. (1992) 'Is the rate of return on primary schooling really 26 per cent?', Journal of African Economies, 1(2), pp. 192-205. 
Independent (2002) 'Shortage of teachers hits primary education', The Independent, June 15.

ILO (1991) Teachers in Developing Countries: A Survey of Employment Conditions (International Labour Office (ILO), Geneva).

Khan, S. R. (2002) 'Rationality in public sector salary scales: The case of rural teachers in Pakistan', Education Economics, 10(3), pp. 333-345.

Kingdon, G. and Teal, Francis (2005) 'Does performance related pay for teachers improve student achievement? Some evidence from India', GPRG Working Paper Series No. 14, University of Oxford.

Liang, Xiaoyan (1999) 'Teacher pay in 12 Latin American countries: How does teacher pay compare to other professions?', LCSHD paper series no 49, The World Bank, Washington, D. C.

Lopez-Acevedo, Gladys (2002) 'Teachers' incentives and professional development in schools in Mexico', The World Bank, Washington, D. C. (processed).

Neuman, Shoshana and Oaxaca, Ronald (2004) 'Wage decompositions with selectivity corrected wage equations: A Methodological Note', Journal of Economic Inequality, 2(1), pp. 3-10.

Oaxaca, Ronald L. (1973) 'Male-female wage differentials in urban labour market', International Economic Review, 9, pp. 693-709.

Podgursky, Michael (2001) 'Relative pay and contractual work hours of New York City teachers, testimony for CFE vs. NYS Trial', University of Missouri (processed).

Podgursky, Michael and Tongrut, Ruttaya (2005) 'Are public school teachers "underpaid"? Some evidence and conjecture', University of Missouri (processed).

PMED (1999) Education for All: The Year 2000 Assessment, Primary and Mass Education Division (PMED), Government of Bangladesh.

Psacharopoulos, G., Valenzuela, J. and Arends, M. (1996) 'Teacher salary in Latin America: A review, Economics of Education Review, 15(4), pp. 401-406.

Piras, Claudia and Savedoff, Bill (1998) 'How much do teachers earn?', Office of the Chief Economists, Working Paper No 375, Inter-American Development Bank, Washington, D.C.

Rivkin, Steven, Hanushek, Eric and Kain, John (2005) 'Teachers, schools, and academic achievement', Econometrica, 79(2), pp. 417-458.

Siniscalco, Maria Teresa (2002) 'A Statistical Profile of Teaching Profession', International Labour Office (ILO), Geneva. 
Vegas, Emilia, Pritchett, Lant and Experton, William (1999) 'Attracting and retaining qualified teachers in Argentina: Impact of the structure and level of compensation', LCSHD Paper Series No. 38, The World Bank, Washington D. C.

\section{Endnotes}

${ }^{1}$ There is ample evidence suggesting a teacher effect on learning (Rivkin et al., 2005). However, whether teacher pay affects student learning in schools in developing and developed countries is not fully conclusive in the literature. See for instance, Harbison and Hanushek (1992), Figlio (1997), Ballou and Podgursky (1997) and, Goldhaber and Brewer (1997).

${ }^{2}$ For similar research on developed countries, see Podgursky (2001), Dolton and Chung (2004) and Podgursky and Tongrut (2005).

${ }^{3} \mathrm{~A}$ similar comparative study of teacher salaries with other professions in developing countries is ILO (1991).

${ }^{4}$ For example, during the period of $1980-96$, the total number of secondary teachers employed in schools grew by 67 percent against a 155 percent increase in total number of secondary students.

5 The NGOs operating in Bangladesh often engage foreign nationals in various development activities. However, none of these individuals teach in the non-formal schools. They generally perform management tasks at the central offices of the NGOs.

${ }^{6}$ However, in the rural areas, schools are often financially constrained to make up for the remaining 20 percent of the salary. This at times drives a wedge in the levels of pay between the rural and urban aided schools.

${ }^{7}$ According to recent press news, 1819 teaching posts fell vacant in 16 (mostly rural) northern districts (Independent, 2002) which were also part of the relatively poorer region of the country.

${ }^{8}$ Hourly earnings were calculated by dividing total monthly earnings by total hours worked.

${ }^{9}$ This sort of sub-setting of data on the basis of educational attainment is a common practice in the studies on teacher pay. See for instance Komenan and Grootaert (1990) and Psacharopoulos et al. (1996). However, this practice implicitly assumes that any sample selectivity created (as a consequence of subsetting) is similar for teachers and non-teachers.

${ }^{10}$ For teacher and non-teacher coefficient vectors $\beta_{\mathrm{t}}$ and. $\beta_{\mathrm{nt}}$ respectively, the weighted average wage structure is: $\hat{\beta}^{*}=\omega \hat{\beta}_{t}+(1-\omega) \hat{\beta}_{n t}$ where $\omega$ is a weighting matrix such that $\omega \in[0,1]$.

${ }^{11}$ Each split creates its associated sample selectivity issues. We are, however, unable to deal with it for a lack of credible exclusion restrictions.

${ }^{12}$ Remaining individuals are classified as 'others' and 'factory' workers. However, we lump these two categories together as 'others' and drop them from our analysis in this part.

${ }^{13}$ These subpopulations are defined by age, an exogenous characteristic, and hence do not involve sample selection issues.

${ }^{14}$ Another related issue of interest is that of "filtering down" (Knight et al., 1992) i.e. whether successive cohorts of teachers at a particular education level enter less skilled jobs within the teaching sector. For example, younger cohorts of teachers may be concentrated more in less responsible positions in schools. However, this may apply to non-teachers as well who, within the non-teaching sector, may enter lesser skilled jobs due to over-expansion of the education system and excess supply of skilled workers.

${ }^{15}$ Earnings profiles are produced using the predicted earnings function evaluated at the mean" $\mathrm{X}$ "value

for respective samples: ${ }^{Y_{i}}=\alpha_{0}+\alpha_{1} E_{i}+\alpha_{2} E_{i}{ }^{2}+\sum \beta_{j} \bar{X}_{i j}$. We do not include a lambda term in that we did not find any evidence of sample selection into waged work for teachers and non-teachers.

${ }^{16}$ Results of the Heckman estimates of wage regression for teachers and non-teachers are available from the author upon request.

${ }^{17}$ Such a problem has been documented by Dreze and Gazdar (1997) for public schools in India that pay teachers far better than private schools. 